\title{
Strategy for Improving Service Performance through Organizational Culture and Climate
}

\author{
Endang Kurnaedi ${ }^{1}$, Kania Agustina ${ }^{2}$, Otong Karyono ${ }^{3}$ \\ ${ }^{1,2}$ Pasundan University, Jawa Barat, Indonesia \\ ${ }^{3}$ Majalengka University, Indonesia \\ ninaangelia3@gmail.com
}

\begin{abstract}
The problem of competition and the demands of changing times towards globalization and modernization are quite dynamic, so that demands high performance and high performance can be realized by the conducive organizational climate and organizational culture that is open to technological and information changes. This study aims to determine the extent of the role and influence of organizational culture and climate on service performance. This research method uses descriptive and verification research. Descriptive research tries to provide an overview of research variables that are able to provide information on current conditions, while verification research to draw a conclusion to provide an explanation of the relationship between variables, so that by doing verification analysis can provide an explanation of the contribution of the magnitude of the relationship or influence and the results of hypothesis testing that was submitted. The results of the study prove that the organizational culture, organizational climate and service performance variables are descriptive in the good category. While the results of the verification study prove that organizational climate has a greater effect on service performance when compared to organizational culture. The results of this study provide recommendations to the $P D$. BPR Sukahaji should always maintain, maintain and even improve the creation of climate and organizational culture, especially for the creation of a work environment related to organizational climate.
\end{abstract}

Keywords

organizational culture;

organizational climate; service

\section{Introduction}

Rapid environmental changes, which are characterized by advances in information, changes in market tastes, changes in demographics, economic fluctuations, and other dynamic conditions require organizations to respond to changes that occur in order to continue to exist in global competition. Companies that survive in a fairly dynamic competitive condition are companies that have competitive advantages that are able to adapt to the environment (Otong Karyono 2018; Paweł Cegliński 2017) by having adequate human resources (Jassim 2014; Kristina et al. 2017) and able provide superior service (Jelčić 2014; Kusumadewi and Karyono 2019). Changes in organizational conditions both internal and external encourage organizations to respond quickly (responsive) and adapt (adaptive) to a market environment full of competition. Organizations must be more flexible to adjust to an increasingly competitive competitive environment. Organizational flexibility is determined by resources that have high ability and skills (knowledge assets) that make the organization has a competitive advantage so that it can win the competition.

One of the business sectors that feels the impact of developments and changes in the global environment is the banking sector. Sukahaji People's Credit Bank Regional Company 
Majalengka Regency in reality also felt the impact of dynamic environmental changes, this was marked by the increasingly intense competition felt by PD. BPR Sukahaji Majalengka Regency with the emergence of financial institutions in the form of banks or other financial services that offer products and services to customers. The increasing number of financial institutions operating in Majalengka Regency has made the community more selective in assessing and choosing the banking services they will use. This makes each financial institution compete to win the competition.

Business PD. BPR Sukahaji Majalengka Regency in setting a standard of quality service to satisfy its customers is carried out seriously, but some of its employees do not carry out well and up to the specified standard. The situation is a gap between service quality standards set by the company and the delivery of service quality to customers by employees, namely the non-delivery of services that have been standardized by the company (Zeithaml, Valarie A 2000). (Lupiyoadi 2001) referred to the situation as a service performance gap, in which employees were unwilling and unable to provide services in accordance with the wishes of management. In previous years, the quality of service provided by PD employees. BPR Sukahaji Majalengka Regency showed good performance. Decrease and gap in service quality that occurs in some PD employees. BPR Sukahaji shows the inconsistency in service. This inconsistency is influenced by the environment of the organization itself. The results of research conducted by (Ram et al. 2011) conducted a study of 369 service employees in India by including aspects of the work environment, service climate and job satisfaction and the results of his research prove there is a strong relationship between work environment and service climate. The results of these studies provide consequences that quality service depends on employees in providing services and employee effectiveness is highly dependent on the conditions of the work environment. (Zeithaml, Valarie A 2000) said that service quality is directly influenced by the behavior of service providers, namely employees. When employee behavior is positive or in accordance with company standards and desires, the quality of service provided by employees is realized. Negative employee behavior or not in accordance with company standards and desires can make it difficult to realize the quality of services provided by employees. It emphasizes that the importance of the quality of work of an employee in realizing quality services, but the quality of employees' work cannot be formed alone but with the support of a cultured organization (Khouly n.d.; Zulkifli and Ali 2017). Added by (Philip Kotler 2009) who said one way to improve competitiveness is to improve service quality, because with good service quality, customer satisfaction will be achieved.

Service quality is a form of performance that is identical to the behavior of employees in the company. Behavior of these employees in the company can be influenced by climate and organizational culture. Organizational climate is a unit based on accepted patterns of employee behavior and special experiences in an organization (Ashkanasy, Neal, Celeste Wilderom 2000). While culture is a component of the organization that involves various aspects that are quite important in supporting the organization, including structure, expected roles and job descriptions, ways to act at work, ways of solving problems, who makes decisions in different situations, and how to behave and behave towards coworkers and superiors, as well as the norms and their application (Tri Sulaksono 2005). Organizational climate can be interpreted as a condition when employees feel a variety of situations that exist in the environment of the organization so as to produce an interpretation of the organization (Smither 1998). Organizational climate can be used as an indicator to describe the work atmosphere that is perceived by employees to interpret and understand the work environment. A positive organizational climate is created when employees perceive 
positively the atmosphere, dimensions, practices, and procedures in the workplace. The result is that employees' attitudes and behavior that arise are positive and supportive towards providing quality services. Whereas culture is defined as culture as a set of assumptions and beliefs. The values and perceptions of group members in an organization shape and influence the attitudes and behavior of the group concerned (Tri Sulaksono 2005). The results of the study indicate that service performance is determined by the atmosphere or climate of the work environment within an organization (Miah 2017a; Sidin, Arifah, and Mahmuda 2019). Other research which states that service performance is determined by organizational culture is carried out by (Furrer and Liu 2000; Hung Trong Hoang, Sally Rao Hill n.d.). Likewise, the PD. BPR Sukahaji in Majalengka Regency, with a program to improve service performance can be achieved by improving the organizational climate more conducive and instilling good organizational culture.

\section{Methodology}

The process of this research is shown to be more familiar with the relationship / influence of the main sections, especially regarding culture and organizational climate on service performance. The conceptualization of the process is then poured into a complete research method with observational analysis patterns and data collection needed to carry out the phenomenon. Therefore the method used in this research is descriptive and verification analysis. In accordance with the basic assumptions and hypotheses in this study that the description in question describes the variables used by the culture and climate of the organization to assess service performance, while the verification analysis to explain the direction of the relationship and the influence of independent variables (culture and organizational climate) on the dependent variable ( service performance).

Data analysis was carried out qualitatively and quantitatively with the aim of obtaining input and a clear picture of the service performance carried out by PD. BPR Sukahaji, Majalengka Regency. The organizational culture in this study consists of people orientation, team orientation, results orientation, aggressiveness and stability (Robbins 2005), while the organizational climate in this study consists of team spirit, responsibility, standard or standard, appreciation, warmth, and support (Gie 2007).

Service performance refers to the theory popularized by parasuraman regarding service quality which consists of physical aspects, empathy, reliability, responsiveness and assurance (Tjiptono 2007). The population in this study were PD employees. Sukahaji BPR Majalengka Regency which amounted to 164 which then performed a sample calculation based on the Slovin formula to 117 people who were selected to be sampled respondents in this study. The reasons for selecting a PD company. BPR Sukahaji as the population in the study was caused by PD. BPR has a strategic role in helping small and medium enterprises (SMEs) especially in providing financial capital. This research uses stratified proportional random sampling. The use of a sampling system with proportional stratified random sampling is because the distribution of the research questionnaire to respondents is determined based on the position of the employee. The data in this study are in the form of primary data and secondary data. Primary data obtained from the results of the distribution of research questionnaires to respondents while secondary data is data in the form of documentation. To analyze data using a path analysis statistical test. This path analysis is an analysis of the relationship / influence between the dependent variable with two or more independent variables. This study uses three instruments derived from theoretical studies and the instrument has been tested to determine its validity. 


\section{Discussion}

In accordance with the objectives of the study, which were divided descriptively and verifiatively, in this study the results of the study were described descriptively about the existing conditions of each variable to get a general picture of how organizational culture variables, organizational climate and service performance at the time the study was conducted. While the purpose of the verification study is to assess the amount of influence of the independent variables on the dependent variable both directly and indirectly.

Table 1. Results of Measurement of Organizational Culture Variables

\begin{tabular}{|c|c|c|c|c|c|c|c|c|}
\hline \multirow[b]{2}{*}{ No } & \multirow{2}{*}{$\begin{array}{c}\text { Organizational Culture } \\
\text { Indicator }\end{array}$} & \multicolumn{6}{|c|}{ Performance Appraisal on each indicator } & \multirow[b]{2}{*}{$\sum$} \\
\hline & & 1 & 2 & 3 & 4 & 5 & $\begin{array}{l}\text { Rata } \\
\text {-rata }\end{array}$ & \\
\hline 1 & Innovation is done & 0 & 0 & 1 & 17 & 99 & 4,85 & 117 \\
\hline 2 & Decision to take & 0 & 2 & 7 & 52 & 56 & 4,38 & 117 \\
\hline 3 & Orientation $\mathrm{t}$ & 0 & 0 & 0 & 27 & 91 & 4,78 & 117 \\
\hline 4 & Team orienta & 0 & 0 & 0 & 6 & 111 & 4,95 & 117 \\
\hline 5 & Orientation towards results & 0 & 2 & 2 & 65 & 48 & 4,36 & 117 \\
\hline 6 & The level of aggressiveness & 0 & 0 & 2 & 48 & 67 & 4,57 & 117 \\
\hline 7 & Degree of stability & 0 & 0 & 1 & 39 & 77 & 4,65 & 117 \\
\hline & Percent (\%) & 0 & 0.49 & 1.6 & 30.91 & 66.9 & 4,72 & 100 \\
\hline
\end{tabular}

Source: Data Processing Results

Table 1 explains that the highest value is found in employee innovation by employees, namely 4.85 (hoping very well) while the lowest is team orientation (hoping good). There were no respondents who wished very badly (1) or hoped badly (2). Overall respondents $66.99 \%$ expect that work innovation, decision making, orientation towards people, teams and results, responsibilities and work stability are expected to be very good so that this spurs and motivates employees to produce better performance.

Table 2. Results of Measurement of Organizational Climate Variables

\begin{tabular}{|c|c|c|c|c|c|c|c|c|}
\hline \multirow{2}{*}{ No } & \multirow{2}{*}{$\begin{array}{l}\text { Organizational Climate } \\
\text { Indicator }\end{array}$} & \multicolumn{6}{|c|}{$\begin{array}{l}\text { Performance Appraisal on each } \\
\text { indicator }\end{array}$} & \multirow{2}{*}{$\sum$} \\
\hline & & 1 & 2 & 3 & 4 & 5 & $\begin{array}{c}\text { Rata- } \\
\text { rata }\end{array}$ & \\
\hline 1 & $\begin{array}{l}\text { Creation of working spirit } \\
\text { in groups }\end{array}$ & 0 & 0 & 9 & 42 & 66 & 4,50 & 117 \\
\hline 2 & $\begin{array}{l}\text { Responsibility for } \\
\text { completing work }\end{array}$ & 0 & 0 & 4 & 69 & 44 & 4,34 & 117 \\
\hline 3 & $\begin{array}{l}\text { Achievement of working } \\
\text { standards }\end{array}$ & & 1 & & 13 & 103 & 4,88 & 117 \\
\hline 4 & Award received & 1 & 1 & 4 & 64 & 48 & 4,34 & 117 \\
\hline 5 & Attention leaders & 0 & 1 & 6 & 36 & 74 & 4,57 & 117 \\
\hline 6 & $\begin{array}{l}\text { Positive support given by } \\
\text { the leadership }\end{array}$ & 0 & 1 & & 25 & 91 & 4,77 & 117 \\
\hline & Percent $(\%)$ & 0,14 & 0,57 & 3,3 & 35,5 & 60,91 & 4,61 & 100 \\
\hline
\end{tabular}

Source: Data Processing Results 
Table 2 explains that the highest value on the organizational climate variable (X2) is found in the achievement of working standards that is equal to 4.88 (hope well). There are no respondents who expect very poorly (1) or expect to have bad expectations (2). Overall, respondents expect very good (5) as much as $60.91 \%$, expect good (4) as much as $35.05 \%$, and the remaining 3.30 expect good enough (3) with an average expectation of 4.61. This means that the majority of respondents $60.91 \%$ hope that the creation of enthusiasm for work, responsibility for completion of work, accuracy of standard work procedures, awards received, attention and support of leaders can run well.

Table 3. Results of Measurement of Organizational Climate Variables

\begin{tabular}{|c|c|c|c|c|c|c|c|c|}
\hline \multirow[b]{2}{*}{ No } & \multirow[b]{2}{*}{ Service Performance Indicators } & \multicolumn{6}{|c|}{ Performance Appraisal on each indicator } & \multirow[b]{2}{*}{$\sum$} \\
\hline & & 1 & 2 & 3 & 4 & 5 & $\begin{array}{l}\text { Rata } \\
\text {-rata }\end{array}$ & \\
\hline 1 & $\begin{array}{l}\text { The level of achievement of the } \\
\text { Bank's performance in fulfilling } \\
\text { the completeness of work } \\
\text { support facilities }\end{array}$ & 0 & 0 & 3 & 29 & 85 & 4,72 & 117 \\
\hline 2 & $\begin{array}{l}\text { The level of achievement of the } \\
\text { Bank's performance in providing } \\
\text { employee attention to customers }\end{array}$ & 0 & 2 & 19 & 63 & 33 & 4,08 & 117 \\
\hline 3 & $\begin{array}{l}\text { The level of achievement of the } \\
\text { Bank's performance in providing } \\
\text { reliability in service }\end{array}$ & 0 & 1 & 9 & 59 & 48 & 4,32 & 117 \\
\hline 4 & $\begin{array}{l}\text { The level of achievement of the } \\
\text { Bank's performance in providing } \\
\text { speed in service }\end{array}$ & 0 & 0 & 2 & 27 & 88 & 4,75 & 117 \\
\hline 5 & $\begin{array}{l}\text { The level of achievement of the } \\
\text { Bank's performance in providing } \\
\text { security to customers }\end{array}$ & 0 & 0 & 3 & 36 & 78 & 4,64 & 117 \\
\hline & Percentage & 0 & 0,51 & 6,20 & 36,5 & 56,72 & 4,54 & 100 \\
\hline
\end{tabular}

Source: Data Processing Results, 2011

Table 3 explains that the highest value on the service performance variable (Y) is in the indicator of the speed of service to customers which is 4.75 (achievement of bank performance in terms of very high speed of service). There were no respondents who stated very low (1) or low (2). Overall respondents stated very high (5) as much as $56.72 \%$, which stated high (4) as much as $36.55 \%$ and the remaining $6.20 \%$ stated quite high (3). This means that the majority of employees $56.72 \%$ expect that banks will pay more attention to the completeness, attention to customers, reliability in service, speed in service and giving a sense of security to customers can be further enhanced, given the increasing level of business competition.

To find out the magnitude of the contribution of the influence of each exogenous variable to endogenous can be calculated from the magnitude of the percentage of influence on each variable, the goal is to determine the amount of increase or decrease in the level of customer satisfaction. How to calculate the direct and indirect effects of exogenous variables on endogenous variables is to pay attention to the value of the path coefficient and the value of the correlation coefficient between exogenous variables, as shown in the figure below. 


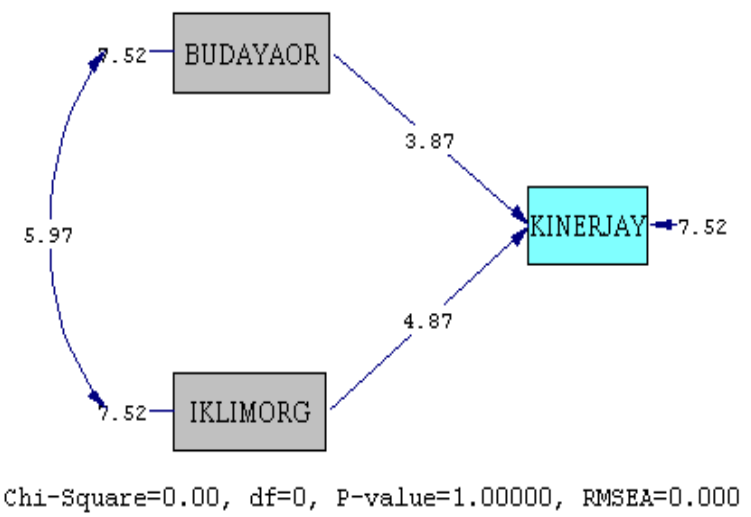

Source: Lisrel results

Figure 1. Diagram of Path Analysis Results on the Variables Researched

Direct Effect $\mathrm{X}_{\mathrm{i}}$ on $\mathrm{Y}=\left(\mathrm{Pyx}_{\mathrm{i}}\right) .\left(\mathrm{Pyx}_{\mathrm{i}}\right)$

The indirect effect of $\mathrm{X}_{\mathrm{i}}$ through $\mathrm{X}_{\mathrm{j}}$ is on $\mathrm{Y}=\left(\mathrm{Pyx}_{\mathrm{i}}\right) \cdot\left(\mathrm{rx}_{\mathrm{i}} \mathrm{x}_{\mathrm{j}}\right)$. $\left(\mathrm{Pyx}_{\mathrm{j}}\right)$

Table 4. Direct effects of $\mathrm{X}_{\mathrm{i}}$ variables on $\mathrm{Y}$

\begin{tabular}{|c|c|c|c|}
\hline Variable & Py. $\mathrm{X}_{\mathrm{i}}$ & Direct effects on $\mathrm{Y}$ & \% Direct effects on $\mathrm{Y}$ \\
\hline $\mathrm{X}_{1}$ & 0,35 & 0,1225 & $12,15 \%$ \\
\hline $\mathrm{X}_{2}$ & 0,44 & 0,1936 & $19,36 \%$ \\
\hline
\end{tabular}

Source: Path Analysis Results Data

Based on the calculation results of path analysis using the help of Lisrel 8.50 software, it is known that the t-value for the organizational culture variable is 3.87 . Whereas the value of $t$-table is 1.960 . The value of 1,960 is the result of the value of $t$-Table $=t_{(0.05,117-3-1) \text {.. Test }}$ criteria: the null hypothesis is rejected if $t>t_{\text {Tabel, }}$, based on these results using a real level $\alpha=$ 0.05 and degrees of freedom $d k=113$, it turns out $\mathrm{t}$-count $=3.87>\mathrm{t}$-Table $=1.960$, meaning the null hypothesis is rejected. So it can be concluded that the path coefficient of the organizational culture variable $\left(\mathrm{X}_{1}\right)$ is significant or in other words the organizational culture variable has a significant influence on service performance. The results of this study support the results of previous studies that have examined the influence of organizational culture on service quality (Furrer and Liu 2000), so that this factor is taken into consideration by organizations to always pay attention to the development of services provided to customers.

Based on the results of the calculation of path analysis using the help of Lisrel 8.50 software, it is known that the $t$-value for the organizational culture variable is 4.87 . Whereas the value of $t$-table is 1.960 . The value of 1,960 is the result of the value of $t$-Table $=t(0.05,117-3-1)$. Test criteria: the null hypothesis is rejected if $\mathrm{t}>\mathrm{t}$ table, based on these results using a real level $\alpha=0.05$ and degrees of freedom $d k=113$, it turns out $\mathrm{t}$-count $=4.87>\mathrm{t}_{\text {-Table }}=1.960$, meaning the null hypothesis is rejected. So it can be concluded that the path coefficient of the organizational climate variable $\left(\mathrm{X}_{1}\right)$ is significant or in other words the organizational climate variable has a significant influence on service performance. The results of this study support the results of previous studies that test organizational climate significantly influence service (Miah 2017b) while the research results (Srijanti Lagonah, Rianoe Pio nd) broaden their findings that organizational climate positively and significantly influences satisfaction 
factors, while findings (Radianto 2017) has the difference that the climate and organizational culture can create reliable performance.

From the results of the analysis to see the causal relationship between culture and organizational climate on service performance at the BPR bank branch Sukahaji-Majalengka using path analysis, shows that there is a significant influence of cultural variables and organizational climate on service performance at a 5\% level. The biggest and strongest influence is given by the organizational climate variable by $29.83 \%$ and is strengthened by the $\mathrm{t}$-value of $4.87>1,960$ ( $\mathrm{t}$-Table), while the influence of the organizational culture variable is $22.62 \%$ the $\mathrm{t}$-value is $3,87>1,960$ (t-Table).

The magnitude of the total effect of all exogenous variables of organizational culture and climate on the structural model of service performance is shown by the magnitude of the coefficient of determination R2 $=0.52$ or $52 \%$. While the outside influence or error of $48 \%$. With the percentage coefficient of determination greater than $50 \%$, it can be concluded that the model formed is included in the good category, so that in this study cultural variables based on the theory of Robbins (2006) and organizational climate based on theories from The Liang Gie in Mulyana (2005) is quite appropriate to be used to measure service performance at a BPR bank in the Sukahaji Majalengka Regency.

\section{Conclusion}

The organizational culture condition of the BPR branch of Sukahaji Majalengka Regency is in very good condition. This is based on the recapitulation of respondents' answers which mostly stated very good (5) of $66.99 \%$. This means that the majority of respondents expect that work innovation, decision making, orientation towards people, teams and results, responsibilities and work stability are expected to be very good so that this stimulates and motivates employees to produce better performance. The organizational climate conditions in the BPR Bank of Sukahaji, Majalengka Regency are in very good condition. This results from respondents' answers that overall respondents expect very good (5) as much as $60.91 \%$, expect good (4) as much as $35.05 \%$, and the rest 3.30 expect good enough (3) with an average expectation of 4.55. This means that the majority of respondents $60.91 \%$ hope that the creation of enthusiasm for work, responsibility for completion of work, accuracy of standard work procedures, awards received, attention and support of leaders can run well. Achievement of the Performance of the BPR Bank Sukahaji Branch Majalengka Regency is currently at a better level than in previous years. This resulted that the majority of respondents stated at $56.72 \%$ better achievement. This means that the majority of employees $56.72 \%$ expect that the company considers more about the completeness, attention to customers, reliability in service, speed in service and giving a sense of security to customers can be further increased, given the increasing level of business competition. Culture and organizational climate simultaneously influence the performance of services by $52 \%$, while partially each gives an influence of 22.62 for organizational culture variables and $29.83 \%$ for organizational climate variables. This means that the better the climate and organizational culture aspects of the BPR bank of the Sukahaji branch of Majalengka Regency, the better the performance of services at the BPR bank of the Sukahaji branch of Majalengka Regency. 


\section{References}

Ashkanasy, Neal, Celeste Wilderom, Mark Peterson. 2000. Handbook Of Organizational Culture and Climate. Thousand Oaks, CA: Sage Publications, Inc.

Furrer, Olivier, and Ben Shaw-ching Liu. 2000. "Between Culture and Service Quality Perceptions Basis for Cross-Cultural Market." Journal of Service Research 2(4): 355-71.

Gie, The Liang. 2007. Administrasi Perkantoran Modern. Yogyakarta: Liberty.

Hung Trong Hoang, Sally Rao Hill, Vinh Nhat Lu. "The Influence of Service Culture on Customer Service Quality: Local vs. Foreign Service Firms in Emerging Markets."

Jassim, Rahim K. 2014. "Competitive Advantage Through the Employees.” (January 1998).

Jelčić, Sandra. 2014. "Managing Service Quality to Gain Competitive Advantage in Retail Environment." TEM Journal 3(2): 181-86. www.temjournal.com.

Khouly, Sayed El. "The Impact of Organizational Culture on Work Quality.” : 210.

Kristina, C̆, Kristina Vai, Ingrida Šapalait, and Aldona Jaraš. 2017. "The Impact of Human Resource Management on the Competitiveness of Transport Companies." Procedia Engineering 187(187): $110-16$.

Kusumadewi, R Neni, and Otong Karyono. 2019. "Impact of Service Quality and Service Innovations on Competitive Advantage in Retailing." Budapest International Research and Critics InstituteJournal (BIRCI-Journal) 2(2): 366-74. https://pdfs.semanticscholar.org/51fc/adc7689ff9cae37f88d175cdf1afa0e87aac.pdf.

Lupiyoadi, Rambat. 2001. Manajemen Pemasaran Jasa, Teori Dan Praktek. Edisi Pertama. Jakarta: Salemba Empat.

Miah, Khasro. 2017a. "Effects of Organizational Climate on Employee Service Quality in Foreign Tobacco Company of Bangladesh Effects of Organizational Climate on Employee Service Quality in Foreign Tobacco Company of Bangladesh." IBT Journal of Business Studies (Formerly Journal of Management \& Social Sciences) 10(January 2014): 1-15.

. 2017b. "Effects of Organizational Climate on Employee Service Quality in Foreign Tobacco Company of Bangladesh Effects of Organizational Climate on Employee Service Quality in Foreign Tobacco Company of Bangladesh." IBT Journal of Business Studies (Formerly Journal of Management \& Social Sciences) (July).

Otong Karyono. 2018. "Membangun Daya Saing Melalui Strategi Bisnis." Prosiding Seminar Nasional dan Call for Papers (November): 182-90.

Paweł Cegliński. 2017. "The Concept of Competitive Advantages. Logic, Sources and Durability." Journal of Positive Management 7(May): 57-70.

Philip Kotler, Kevin Lane Keller. 2009. Marketing Management. London: Pearson Education. http://library.um.ac.id/free-contents/printbook2.php/koleksi-digital-perpustakaan-38562.html.

Radianto, Ari. 2017. "Pengaruh Iklim Organisasi Dan Budaya Organisasi Terhadap Kinerja Karyawan (Studi Pada Karyawan PT.PG Krebet Baru Malang)." Jurnal Administrasi Bisnis (JAB)| 53(1): 14-20.

Ram, Padmakumar et al. 2011. "Work Environment, Service Climate, and Customer Satisfaction: Examining Theoretical and Empirical Connections." International Journal of Business and Social Science 2(20): 121-32.

Robbins, Stephen. 2005. Organizational Behavior. New Jersey: Pearson Educational International.

Sidin, Indahwaty, Nur Arifah, and Rifa Mahmuda. 2019. "Organizational Climate Enhance Service Quality through Enhancing OCB in Public Hospital ." Biomedical Research 2019; 30(5): 73846.

Smither, R. D. 1998. The Psychology of Work and Human Performance. Third Edition. New York: Longman Inc.

Srijanti Lagonah, Rianoe Pio, Markus Kaunang. "Pengaruh Iklim Organisasi Dan Budaya Organisasi Terhadap Kepuasan Kerja Pegawai Kantor Pertanahan Kota Manado.”

Tjiptono, Fandy. 2007. Strategi Pemasaran. Yogyakarta: Andi.

Tri Sulaksono. 2005. "Budaya Organisasi Dan Ketidakpastian Lingkungan Sebagai Variabel Moderating Dalam Hubungan Antara Gaya Evaluasi Atasan Terhadap Tekanan Kerja Dan 
Kepuasan Kerja Bawahan.” Universitas Diponegoro.

Zeithaml, Valarie A, Bitner. 2000. Service Marketing 2nd Edition: Integrating Customer Focus. New York: McGraw-Hill Inc.

Zulkifli, Nordayana, and Kalsom Ali. 2017. "Accentuating The Positive Organizational Behaviour and Work Engagement Concepts Towards Job Performance Quality of Public Sector Staff in Wilayah Persekutuan Putrajaya.” Humanities \& Social Science Reviews 5(2): 134-40. 